\title{
Prevalence, comorbidities, diagnosis, and treatment of nonallergic rhinitis: real-world comparison with allergic rhinitis
}

\author{
Hye Yung Yum, MD, PhD ${ }^{1, *}$, Eun Kyo Ha, MD ${ }^{2, *}$, Yoon Ho Shin, MD, PhD ${ }^{3}$, Man Yong Han, $\mathrm{MD}^{4}$ \\ ${ }^{1}$ Department of Pediatrics, Seoul Medical Center, Seoul, Korea; ${ }^{2}$ Department of Pediatrics, Kangnam Sacred Heart Hospital, Hallym University College of Medicine, \\ Seoul, Korea; ${ }^{3}$ Department of Pediatrics, CHA Gangnam Medical Center, CHA University School of Medicine, Seoul, Korea; ${ }^{4}$ Department of Pediatrics, CHA Bundang \\ Medical Center, CHA University School of Medicine, Seongnam, Korea
}

Rhinitis is among the most common respiratory diseases in children. Nonallergic rhinitis, which involves nasal symptoms without evidence of systemic allergic inflammation or infection, is a heterogeneous entity with diverse manifestations and intensities. Nonallergic rhinitis accounts for $16 \%-89 \%$ of the chronic rhinitis cases, affecting 1\%-50\% (median 10\%) of the total pediatric population. The clinical course of nonallergic rhinitis is generally rather mild and less likely to be associated with allergic comorbidities than allergic rhinitis. Here, we aimed to estimate the rate of coexisting comorbidities of nonallergic rhinitis. Nonallergic rhinitis is more prevalent during the first 2 years of life; however, its underestimation for children with atopic tendencies is likely due to low positive rates of specific allergic tests during early childhood. Local allergic rhinitis is a recently noted phenotype with rates similar to those in adults (median, 44\%; range, 4\%-67\%), among patients previously diagnosed with nonallergic rhinitis. Idiopathic rhinitis, a subtype of nonallergic rhinitis, has been poorly studied in children, and its rates are known to be lower than those in adults. The prevalence of nonallergic rhinitis with eosinophilia syndrome is even lower. A correlation between nonallergic rhinitis and pollution has been suggested owing to the recent increase in nonallergic rhinitis rates in highly developing regions such as some Asian countries, but many aspects remain unknown. Conventional treatments include antihistamines, intranasal corticosteroids, and recent treatments include combination of intranasal corticosteroids with azelastin or decongestants. Here we review the prevalence, diagnosis, comorbidities, and treatment recommendations for nonallergic rhinitis versus allergic rhinitis in children.

Key words: Rhinitis, Prevalence, Nonallergic rhinitis

\section{Key message}

- Rhinitis is among the most common respiratory diseases in children.

- Nonallergic rhinitis is a heterogeneous entity involving nasal symptoms without evidence of systemic inflammation or infection.

- The prevalence and etiology of some phenotypes of nonallergic rhinitis in children are well defined, but information about other rhinitis phenotypes remains uncertain.

- Comprehensive understanding to childhood nonallergic rhinitis might enable to provide accurate diagnostic and therapeutic approaches to childhood nonallergic rhinitis.

\section{Introduction}

Chronic rhinitis, among the most common respiratory diseases in childhood, is characterized by nasal symptoms including rhinorrhea, nasal obstruction, sneezing, and itching. ${ }^{1,2)}$ A significant proportion of patients in clinical practice with typical rhinitis signs and/or symptoms but no evidence of allergen sensitization are classified as having nonallergic rhinitis. ${ }^{3,4)}$ Nonallergic rhinitis is a heterogeneous entity whose symptoms may be persistent or intermittent and phenotypes include nonallergic rhinitis with eosinophilia (NARES), hormonal rhinitis, atopic rhinitis, druginduced rhinitis, gustatory rhinitis, and idiopathic rhinitis. ${ }^{5)}$

Recognition of the differentiation between nonallergic rhinitis, allergic rhinitis, and other chronic rhinitis is essential in the clinical setting considering the fact that it has various phenotypes. 6,7) There is a paucity of clinical studies on managing children with nonallergic rhinitis, as data on its diagnosis, classification, etiology, treatment, and natural history are insufficient, especially in childhood. Here we review the prevalence, clinical presentation, comorbidities, and management of nonallergic rhinitis in children. 


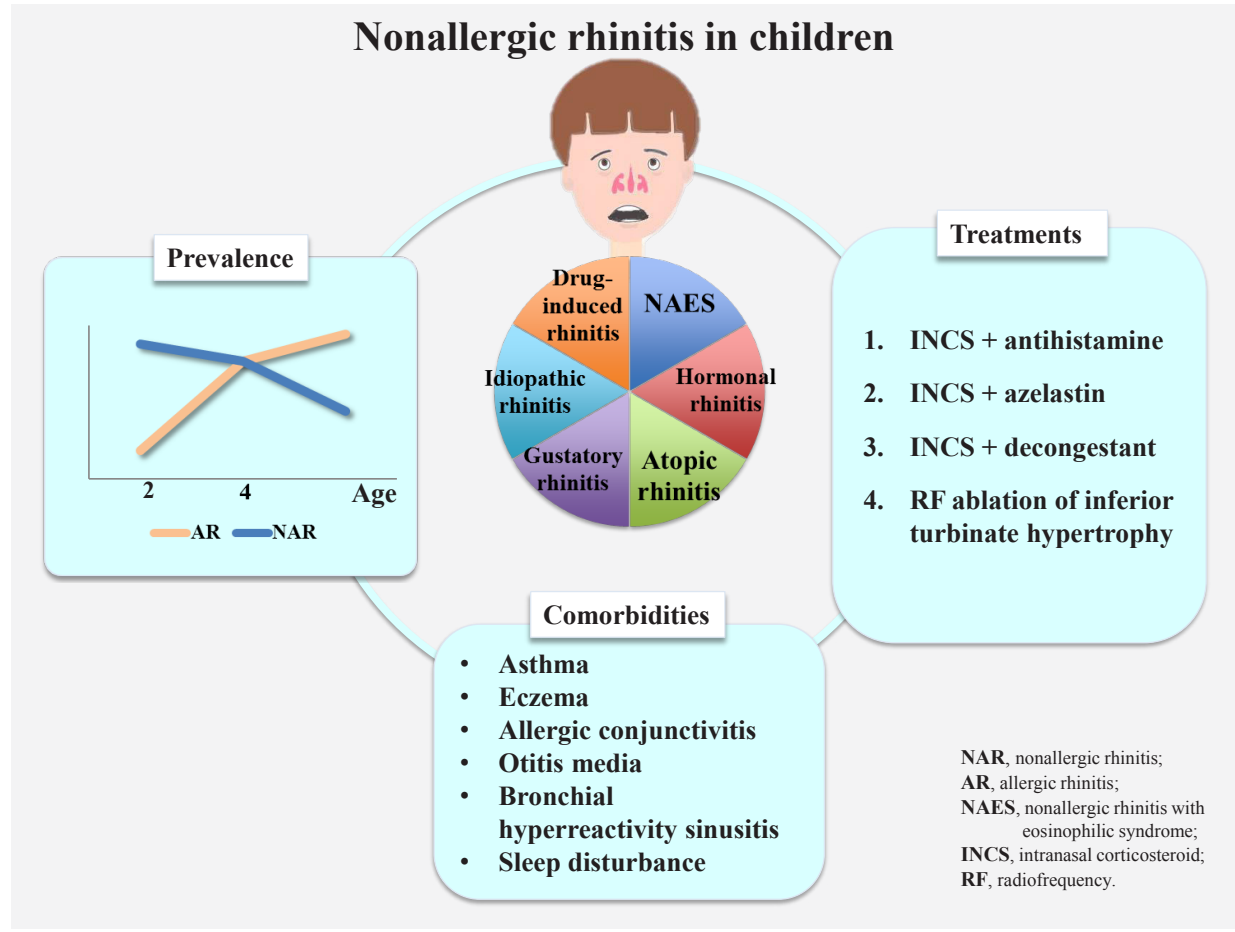

Graphical abstract

\section{Epidemiology of nonallergic rhinitis in children}

Nonallergic rhinitis is a diagnosis of exclusion that is characterized by signs and/or symptoms similar to allergic rhinitis (e.g., rhinorrhea, nasal obstruction, nasal itching, and sneezing after allergen exposure). After the exclusion of allergic rhinitis based on the identification of allergen sensitizations, nonallergic rhinitis is suspected and efforts are made to identify associated conditions like sinusitis or adenoid hypertrophy. ${ }^{7,8)}$ Studies have reported that the prevalence of nonallergic rhinitis is $0.7 \%-50.0$ $\%$ (median, $10.1 \%$ ) in pediatric population. Nonallergic rhinitis seems to account for $15.7 \%-89.0 \%$ of the chronic rhinitis cases (Table 1).

In epidemiologic studies, decreasing trends in the incidence of nonallergic rhinitis were observed, while the incidence of allergic rhinitis increased with age. ${ }^{9)}$ In a birth cohort from the United Kingdom, a decreasing trend in the proportion of children with symptomatic rhinitis was estimated at $79 \%, 45 \%$, and $42.3 \%$, respectively, at 2, 4, and 10 years of age. ${ }^{10-13)}$ Similar results were observed in a prospective birth cohort study (Multicenter Allergy Study) that assessed 1,314 children. ${ }^{14)}$ In another birth cohort study from Sweden, the prevalence increased from 5.4\% to $14 \%$ and that of nonallergic rhinitis decreased from $8.1 \%$ to $6.3 \%$ at 4 and 8 years of age, respectively. ${ }^{15)}$ Other birth cohorts reported that the rate of rhinitis in children was similar to that of nonallergic rhinitis from 5 to 7 years of age. ${ }^{16,17)}$ A recent study of a Korean population reported that the prevalence of allergic rhinitis increased from $22.1 \%$ to $28.3 \%$ from 7 to 12 years of age, while that of nonallergic rhinitis decreased from $21.3 \%$ to $13.3 \%{ }^{18)}$

Considering the data of the studies mentioned above, nonallergic rhinitis is found to be prevalent in children younger than 2 years with chronic rhinitis, and the proportion tends to decrease with age, whereas the proportion of allergic rhinitis increases.

\section{Clinical manifestation of nonallergic rhinitis in children}

Children with nonallergic rhinitis are known to experience milder nasal signs and/or symptoms, and nonallergic rhinitis takes a less severe clinical course than allergic rhinitis. ${ }^{19-21)}$ Signs and/or symptoms of nonallergic rhinitis seem to be transient, while those of allergic rhinitis persist; this disparity increases with age. ${ }^{15)}$

\section{Comorbidities of nonallergic rhinitis in children}

Studies reported that rates of comorbid disorders were lower in children with nonallergic rhinitis than in those with allergic rhinitis. ${ }^{3,18)}$ Nevertheless, children with nonallergic rhinitis have a higher prevalence of various concurrent disorders than the general pediatric population. Various comorbidities are involved in children with nonallergic rhinitis, including asthma, eczema, allergic conjunctivitis, otitis media, bronchial hyperreactivity, sinusitis, sleep disturbances, and bronchial hyperreactivity (Table 2).

Eczema and asthma often coexist in rhinitis children with or without immunoglobulin $\mathrm{E}$ (IgE) sensitization, which has been proven in slightly more than one third of children with comorbidities. $^{22)}$ This finding implies that IgE sensitization may not be 
Table 1. Prevalence of rhinitis among general pediatric population with and without allergic sensitization proven by skin prick tests or serum-specific immunoglobulin E levels

\begin{tabular}{|c|c|c|c|c|c|c|c|c|c|}
\hline \multirow[b]{2}{*}{ Study } & \multirow[b]{2}{*}{ Regions } & \multirow[b]{2}{*}{$\begin{array}{l}\text { Survey years } \\
\text { (otherwise } \\
\text { mentioned) }\end{array}$} & \multirow[b]{2}{*}{ Diagnosis } & \multirow[b]{2}{*}{$\mathrm{N}$} & \multirow[b]{2}{*}{$\begin{array}{l}\text { Age } \\
(y r)\end{array}$} & \multicolumn{3}{|c|}{ Group, \% (n) } & \multirow[b]{2}{*}{ Comments } \\
\hline & & & & & & Rhinitis & $\begin{array}{l}\text { Allergic } \\
\text { rhinitis }\end{array}$ & $\begin{array}{l}\text { Non } \\
\text { allergic } \\
\text { rhinitis }\end{array}$ & \\
\hline Sears et al. ${ }^{98)}$ & $\begin{array}{l}\text { New } \\
\text { Zealand }\end{array}$ & $1993^{h)}$ & $\begin{array}{l}\text { Physician-administered respi- } \\
\text { ratory questionnaire, skin prick } \\
\text { test }\end{array}$ & 662 & $11-13$ & 27.3 & 30 & 6.3 & $\begin{array}{l}\text { Birth cohort for children born between } \\
\text { 1972-1973 }\end{array}$ \\
\hline Porro et al. ${ }^{99)}$ & Italy & $1993^{h)}$ & $\begin{array}{l}\text { Standardized anamnestic ques- } \\
\text { tionnaire, skin prick test }\end{array}$ & 2,304 & 6 & 8.2 & 3.6 & 4.6 & \\
\hline $\begin{array}{l}\text { Braun-Fahrlander } \\
\text { et al. }^{100)}\end{array}$ & $\begin{array}{l}\text { Switzer- } \\
\text { land }\end{array}$ & 1992-1993 & ISAAC, skin prick test & 2,120 & $\begin{array}{l}7,10 \\
14\end{array}$ & 23.7 & $10.1^{\mathrm{a})}$ & $13.6^{a)}$ & $\begin{array}{l}\text { a) Prevalence calculated by tracing sensi- } \\
\text { tivity data }\end{array}$ \\
\hline Arshad et al. ${ }^{11)}$ & UK & $1993-1994^{\mathrm{g})}$ & $\begin{array}{l}\text { Clinical diagnosis by physicians } \\
\text { using questionnaires and phy- } \\
\text { sical examination, skin prick test }\end{array}$ & $981\left(946^{b)}\right)$ & 4 & 6.1 & $3.5^{b)}$ & $2.9^{b)}$ & $\begin{array}{l}\text { Birth cohort for children born between } \\
1989-1990 \\
\text { b) Rates among children who performed } \\
\text { skin prick tests }\end{array}$ \\
\hline Wright et al. ${ }^{101)}$ & USA & 1994 & $\begin{array}{l}\text { Diagnosed by doctor, skin prick } \\
\text { test }\end{array}$ & 747 & 6 & 41.5 & 17.3 & 17.3 & $\begin{array}{l}\text { No skin test data for } 53 \text { of the rhinitis } \\
\text { patients }\end{array}$ \\
\hline Keles et al. ${ }^{102)}$ & Turkey & 1996-1997 & $\begin{array}{l}\text { Turkish version of American Soci- } \\
\text { ety Questionnaire, skin prick test }\end{array}$ & $\begin{array}{l}\text { Unpolluted } 198 \\
\text { Polluted } 188\end{array}$ & $\begin{array}{l}15-17 \\
15-17\end{array}$ & $\begin{array}{r}6.1 \\
22.9\end{array}$ & $\begin{array}{r}4.1 \\
11.7\end{array}$ & $\begin{array}{r}1.5 \\
11.2\end{array}$ & \\
\hline $\begin{array}{l}\text { Soto-Quiros } \\
\text { et al. }^{103)}\end{array}$ & $\begin{array}{l}\text { Costa } \\
\text { Rica }\end{array}$ & 1998 & ISAAC, skin prick test & $306\left(107^{c}\right)$ & 10 & $\begin{array}{c}53.6 \\
\left(61.8^{c}\right)\end{array}$ & 11.8 & 50.0 & $\begin{array}{l}\text { c) Prevalence of rhinitis in children with SPT } \\
\text { results provided }\end{array}$ \\
\hline $\begin{array}{l}\text { Kurukulaaratchy } \\
\text { et al. }{ }^{104)}\end{array}$ & UK & $2011^{\mathrm{h})}$ & ISAAC, skin prick test & $\begin{array}{l}1,214\left(980^{d)}\right) \\
1,362\left(1,036^{d}\right) \\
1,309\left(853^{d)}\right)\end{array}$ & $\begin{array}{c}4 \\
10 \\
18\end{array}$ & $\begin{array}{r}5.4 \\
22.6 \\
35.8\end{array}$ & $\begin{array}{r}3.4 \\
13.3 \\
27.3\end{array}$ & $\begin{array}{r}2.8 \\
12.6 \\
11.8\end{array}$ & $\begin{array}{l}\text { Birth cohort for children born between } \\
\text { 1989-1990d) SPT performed in sympto- } \\
\text { matic children only }\end{array}$ \\
\hline Kuyucu et al. ${ }^{105)}$ & Turkey & 1999-2000 & ISAAC, skin prick test & 2,774 & $8-11$ & 30.6 & 6.2 & 24.4 & \\
\hline Carr et al. ${ }^{106)}$ & USA & $1986-1992^{\mathrm{g})}$ & $\begin{array}{l}\text { Questionnaires about the respi- } \\
\text { ratory health, skin prick test }\end{array}$ & 521 & 6 & 38.0 & 16.7 & 21.3 & $\begin{array}{l}\text { Tucson Children's Respiratory Study, birth } \\
\text { cohort for children born between 1980- } \\
1986\end{array}$ \\
\hline $\begin{array}{l}\text { Papadopoulou } \\
\text { et al. }^{107)}\end{array}$ & Greece & 2000-2001 & ISAAC, skin prick test & 2,023 & $9-10$ & 19.0 & 5.9 & 13.2 & \\
\hline Ulrik et al. ${ }^{108)}$ & Denmark & 1993-20009) & ISAAC, skin prick test & 408 & $7-17$ & 14.5 & 12.3 & 2.2 & Children born in 1986 \\
\hline Westman et al. ${ }^{15)}$ & Sweden & $\begin{array}{l}1998-2000^{g)} \\
2002-2004^{9}\end{array}$ & ISAAC, ImmunoCAP & 2,024 & $\begin{array}{l}4 \\
8\end{array}$ & $\begin{array}{l}13.5 \\
20.3\end{array}$ & $\begin{array}{r}5.4 \\
14.0\end{array}$ & $\begin{array}{l}8.1 \\
6.3\end{array}$ & $\begin{array}{l}\text { Birth cohort for children born between } \\
\text { 1994-1996 }\end{array}$ \\
\hline Belgrave et al. $^{109)}$ & UK & $2014^{h)}$ & ISAAC, ImmunoCAP & 6,427 & 8 & 24.4 & 10.7 & 13.7 & $\begin{array}{l}\text { Manchester Asthma and Allergy Study, } \\
\text { 1995-1997; Avon Longitudinal Study of } \\
\text { Parents and Children, 1991-1992 }\end{array}$ \\
\hline Bahceciler et al. ${ }^{110)}$ & Turkey & 2001 & ISAAC, skin prick test & $1,018\left(1,002^{\mathrm{e}}\right)$ & 4-12 & 26.2 & 6.2 & 19.6 & e) Number of children with SPT results \\
\hline $\begin{array}{l}\text { Kurukulaaratchy } \\
\text { et al. }{ }^{111)}\end{array}$ & Denmark & 2001 & ISAAC, skin prick test & 225 & 6 & 33.0 & 9.0 & 24.0 & $\begin{array}{l}\text { Copenhagen Prospective Studies on } \\
\text { Asthma in Childhood (COPSAC) }\end{array}$ \\
\hline Kim et al. ${ }^{112)}$ & $\begin{array}{l}\text { South } \\
\text { Korea }\end{array}$ & $2002^{h)}$ & $\begin{array}{l}\text { Diagnosed by doctors, skin prick } \\
\text { test }\end{array}$ & 1,727 & $16-18$ & 13.6 & 11.2 & 2.4 & 98 missing SPT results \\
\hline Bertelsen et al. ${ }^{113)}$ & Norway & 2002 & ISAAC, skin prick test & 1,015 & 10 & 25 & 6.8 & 18.1 & $\begin{array}{l}\text { AR and NAR classified by inhalant allergen } \\
\text { sensitization }\end{array}$ \\
\hline $\begin{array}{l}\text { Sobki and } \\
\text { Zakzouk }^{114)}\end{array}$ & $\begin{array}{l}\text { Saudi } \\
\text { Arabia }\end{array}$ & $2004^{h)}$ & ISAAC, skin prick test & 9,540 & $6-15$ & 26.5 & 16.4 & 10.1 & \\
\hline Herr et al. ${ }^{23)}$ & France & $2004-2005^{\mathrm{g})}$ & ISAAC, ImmunoCAP & 1,850 & 1.5 & 9.1 & 0.16 & 9.0 & $\begin{array}{l}\text { PARIS (Pollution and Asthma Risk: an } \\
\text { Infant Study) cohort, children born in } \\
2003\end{array}$ \\
\hline Kong et al. ${ }^{115)}$ & China & 2005 & ISAAC, skin prick test & 1,211 & $3-6$ & 27.1 & 7.8 & 11.9 & \\
\hline Han et al. ${ }^{116)}$ & USA & 2005-2006 & Diagnosis by physician, ImmunoCAP & 2,358 & $6-17$ & 16.8 & 12.5 & 7.0 & \\
\hline Zhang et al. ${ }^{117)}$ & China & 2007 & ISAAC, skin prick test & 4,075 & $3-5$ & 48.0 & 14.9 & 33.1 & \\
\hline Chawes et al. ${ }^{17)}$ & Denmark & $2008^{g)}$ & ISAAC, skin prick test & 290 & 7 & 36 & 26 & 10 & COPSAC \\
\hline Pinart et al. ${ }^{22)}$ & $\begin{array}{l}12 \text { Euro- } \\
\text { pean birth } \\
\text { cohorts }\end{array}$ & $2007-2014^{\mathrm{g})}$ & ISAAC, serum-specific-IgE & $8,366^{f)}$ & 4 & 2.9 & 1.1 & 0.7 & $\begin{array}{l}\text { Children born in } 2008^{f)} 3356 \text { children had } \\
\text { no information available for serum- } \\
\text { specific-lgE test results. }\end{array}$ \\
\hline Hardjojo et al. ${ }^{24)}$ & Singapore & $2010-2011^{g)}$ & ISAAC, skin prick test & 733 & 1.5 & 32.1 & 5.6 & 26.5 & $\begin{array}{l}\text { Growing Up in Singapore towards healthy } \\
\text { outcomes (GUSTO) birth cohort }\end{array}$ \\
\hline Lee et al. ${ }^{118)}$ & Korea & 2015 & $\begin{array}{l}\text { Questionnaires completed by } \\
\text { parents }\end{array}$ & 122 & $\begin{array}{l}7 \\
9\end{array}$ & $\begin{array}{l}30.3 \\
21.3\end{array}$ & $\begin{array}{l}14.8 \\
11.5\end{array}$ & $\begin{array}{r}15.6 \\
9.8\end{array}$ & Snoring child cohort \\
\hline
\end{tabular}

AR, allergic rhinitis; ISAAC, International Study of Asthma and Allergies in Children; NAR, nonallergic rhinitis; SPT, skin prick test.

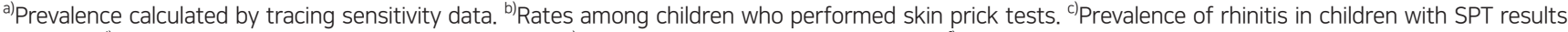
provided. ${ }^{d)}$ SPT performed in symptomatic children only. ${ }^{\text {e) }}$ Number of children with SPT results. ${ }^{f} 3356$ children had no information available for serumspecificIgE test results. ${ }^{9}$ Test year calculated using birth year and test age mentioned in the study. ${ }^{\text {h) }}$ Published year of papers that did not mention test year. 
Table 2. Comorbidities and phenotypes of rhinitis for children with allergic versus nonallergic rhinitis

\begin{tabular}{|c|c|c|c|c|}
\hline Comorbidity & Study & $\begin{array}{l}\text { Age } \\
\text { (yr) }\end{array}$ & $\begin{array}{l}\text { AR } \\
(\%)\end{array}$ & $\begin{array}{l}\text { NAR } \\
(\%)\end{array}$ \\
\hline \multirow[t]{14}{*}{ Asthma } & Westman et al. ${ }^{15)}$ & 4 & 28.0 & 12.7 \\
\hline & & 8 & 25.5 & 11.0 \\
\hline & Chawes et al. ${ }^{17)}$ & 7 & $21.0^{\dagger}$ & $19.4^{\dagger}$ \\
\hline & Bertelsen et al. ${ }^{113), a)}$ & 10 & $34.3^{\dagger}$ & $25.0^{\dagger}$ \\
\hline & Wright et al. ${ }^{101)}$ & 6 & 32 & 14 \\
\hline & Lee et al. ${ }^{119)}$ & $<18$ & 29.9 & 10.3 \\
\hline & Pinart et al. ${ }^{22)}$ & 4 & 35.8 & 15.8 \\
\hline & & 8 & 50.7 & 26.7 \\
\hline & Ahn et al. ${ }^{120)}$ & $2-16$ & 23.1 & 4.3 \\
\hline & Ha et al. ${ }^{25)}$ & 6 & 26.7 & 25.4 \\
\hline & Kim et al. ${ }^{121)}$ & $10-11$ & 17.4 & 13.4 \\
\hline & Won et al. ${ }^{122)}$ & $1-16$ & 29.7 & 17.2 \\
\hline & Molgaard et al. ${ }^{123)}$ & $14-44$ & 51.2 & 38.6 \\
\hline & Chiang et al. ${ }^{9)}$ & $0.6-19$ & $\begin{array}{r}33.0 \\
\left(9.1^{b}\right)\end{array}$ & $\begin{array}{c}23.1 \\
\left(6.0^{b}\right)\end{array}$ \\
\hline \multirow[t]{11}{*}{ Eczema } & Westman et al. ${ }^{15)}$ & 4 & 50.0 & 29.8 \\
\hline & & 8 & 32.4 & 28.2 \\
\hline & Chawes et al. ${ }^{17)}$ & 7 & $66+$ & $43^{\dagger}$ \\
\hline & Lee et al. ${ }^{119)}$ & $<18$ & 29.1 & 35.1 \\
\hline & Pinart et al. ${ }^{22)}$ & 4 & 51.9 & 52.6 \\
\hline & & 8 & 59.2 & 53.3 \\
\hline & Bertelsen et al. ${ }^{113), a)}$ & 10 & $\begin{array}{c}20.5^{\mathrm{e})} \\
\left(27.5^{f)}\right)\end{array}$ & $\begin{array}{c}18.8^{\mathrm{e})} \\
\left(31.4^{f)}\right)\end{array}$ \\
\hline & Ahn et al. ${ }^{120)}$ & $2-16$ & 16.5 & 14.9 \\
\hline & Won et al. ${ }^{122)}$ & $1-16$ & 30.9 & 25.6 \\
\hline & Ha et al. ${ }^{25)}$ & 6 & 38.4 & 0.0 \\
\hline & Chiang et al. ${ }^{9)}$ & $0.6-19$ & 36.1 & 27.6 \\
\hline \multirow[t]{4}{*}{ Conjunctivitis } & Bertelsen et al. ${ }^{113), a)}$ & 10 & 85.9 & 47.8 \\
\hline & Lee et al. ${ }^{119)}$ & $<18$ & 37.5 & 11.2 \\
\hline & Kim et al. ${ }^{124)}$ & $6-15$ & 55.7 & 25.5 \\
\hline & Chiang et al. ${ }^{9}{ }^{9}$ & $0.6-19$ & 18.3 & 9.2 \\
\hline
\end{tabular}

the dominant causal mechanism of comorbidity for these diseases. Concurrent diagnosis and comorbidities among children in different rhinitis groups are shown in Table 2. Taken together, these data suggest that children with allergic rhinitis have higher rates of some IgE-mediated comorbidities (asthma, food hypersensitivity, oral allergy syndrome, and bronchial hyperactivity), whereas other comorbidity rates are similar or even higher in children with nonallergic rhinitis. Further studies are necessary to understand the comorbidities in patients of different ages and with natural courses of nonallergic rhinitis in the general population.

\section{Actual considerations for recurrent or chronic rhinitis in children younger than 2 years of age}

Despite the availability of weak data regarding infantile rhinitis, previous studies have reported that the prevalence of nonallergic rhinitis in children younger than 2 years is estimated at $1.9 \%-9.0 \%$. In a study from Singapore, $66.7 \%$ of the chronic
Table 2. Continued

\begin{tabular}{|c|c|c|c|c|}
\hline Comorbidity & Study & $\begin{array}{l}\text { Age } \\
\text { (yr) }\end{array}$ & $\begin{array}{l}A R \\
(\%)\end{array}$ & $\begin{array}{l}\text { NAR } \\
(\%)\end{array}$ \\
\hline \multirow[t]{4}{*}{ Otitis media } & Bertelsen et al. ${ }^{113), a)}$ & 10 & 10.3 & 5.8 \\
\hline & Lee et al. ${ }^{119)}$ & $<18$ & 10.1 & 3.8 \\
\hline & Ahn et al. ${ }^{120)}$ & $<18$ & 11.2 & 6.5 \\
\hline & Won et al. ${ }^{122)}$ & $1-16$ & 11.2 & 6.5 \\
\hline \multirow[t]{4}{*}{ Sinusitis } & Lee et al. ${ }^{119)}$ & $<18$ & 42.8 & 38.2 \\
\hline & Ahn et al. ${ }^{120)}$ & $2-16$ & 29.2 & 41.3 \\
\hline & Won et al. ${ }^{122)}$ & $1-16$ & 31.0 & 27.8 \\
\hline & Molgaard et al. ${ }^{123)}$ & $14-44$ & 7.1 & 14.8 \\
\hline \multirow[t]{3}{*}{ Sleep disturbance } & Lee et al. ${ }^{119)}$ & $<18$ & 33.4 & 27.2 \\
\hline & Won et al. ${ }^{122)}$ & $1-16$ & 3.4 & 5.4 \\
\hline & Ahn et al. ${ }^{120)}$ & $2-16$ & 36.0 & 30.4 \\
\hline \multirow[t]{2}{*}{ Food hypersensitivity } & Westman et al. ${ }^{15)}$ & 4 & 38.1 & 17.7 \\
\hline & & 8 & 51.1 & 13.4 \\
\hline \multirow[t]{2}{*}{ Oral allergy syndrome } & Westman et al. ${ }^{15)}$ & 8 & 24.8 & 2.5 \\
\hline & Lee et al. ${ }^{119)}$ & $<18$ & 4.8 & - \\
\hline \multirow[t]{2}{*}{ Bronchial hyperreactivityc) } & Kim et al. ${ }^{124)}$ & $6-15$ & 55.6 & 25.5 \\
\hline & Molgaard et al. ${ }^{123)}$ & $14-44$ & 34.9 & 19.9 \\
\hline $\begin{array}{l}\text { Exercise induced } \\
\text { bronchoconstriction }\end{array}$ & Bertelsen et al. ${ }^{1133, a)}$ & 10 & 25.6 & 11.3 \\
\hline Hypertrophy of adenoids & Topal et al. ${ }^{20)}$ & $6-18$ & 18.2 & 25 \\
\hline Anaphylaxis & Bertelsen et al. ${ }^{13), a)}$ & 10 & 2.7 & 1.4 \\
\hline \multirow[t]{2}{*}{ Bronchitis } & Wright et al. ${ }^{101)}$ & 6 & 30 & 23 \\
\hline & Chiang et al. ${ }^{9)}$ & $0.6-19$ & $8.6^{b)}$ & $9.9^{b)}$ \\
\hline Pneumonia & Chiang et al. ${ }^{9)}$ & $0.6-19$ & $4.2^{b)}$ & $4.3^{\mathrm{b})}$ \\
\hline Headaches & Molgaard et al. ${ }^{123)}$ & $14-44$ & 11.0 & 25.5 \\
\hline Nasal polyposis & Geraldi et al. $^{125)}$ & $4-84$ & 38.4 & 19.6 \\
\hline
\end{tabular}

AR, allergic rhinitis; NAR, nonallergic rhinitis.

a) Bertelsen et al. classified allergic versus nonallergic rhinitis depending on sensitization to inhalant allergens. ${ }^{\text {b) }}$ Rates among children with skin prick test results. ${ }^{c} 20 \%$ decrease in forced expiratory volume in 1 second. ${ }^{\text {e) }}$ Previous account of reported symptoms. ${ }^{\text {f) }}$ Current account of reported symptoms during the last 12 months.

rhinitis patients under 2 years of age were diagnosed with nonallergic rhinitis, while up to $15.5 \%$ were diagnosed with nonallergic rhinitis after 6 years of age, which was higher than the reported estimated prevalence among patients younger than 2 years of age. ${ }^{9)}$

A birth cohort from France reported that 9.1\% (169 of 1,850) of the enrolled children aged 18 months experienced rhinitis symptoms, which were significantly associated with a parental history of allergic rhinitis in early childhood. Among them, only $5.5 \%$ (9 of 169) were sensitized to inhalant allergens, while the remainder of the patients were categorized as having nonallergic rhinitis according to their clinical features and laboratory findings. ${ }^{23)}$ Another birth cohort from Singapore (Growing Up in Singapore Towards healthy Outcomes) of young infants aged 18 months reported that prolonged/recurrent rhinitis was significantly associated with parental atopy, but not with allergen sensitizations. ${ }^{24)}$ Rhinitis symptoms in early childhood are common, but epidemiological data are insufficient. Data derived from population-based birth cohort studies suggest that a complex association may exist between rhinitis symptoms and family 
history, comorbidities, allergen sensitization, and aggravating/ risk factors and that children with atopic tendency may be prone to developing allergic rhinitis later in life. Since sensitization is difficult to prove using objective tools (e.g., skin prick test) in early childhood, the possibility of underestimation in children who are actually atopic must also be considered in managing children diagnosed with nonallergic rhinitis during the second year of life.

\section{Local allergic rhinitis in children}

Local allergic rhinitis (LAR), a rhinitis phenotype recognized during the last decade, is characterized by allergen-related nasal hyper-reactivity despite the absence of specific systemic atopy and is diagnosed using specific nasal provocation tests (NPTs). ${ }^{5,25)}$ A systematic review of 46 adult studies showed positive NPT results of $86.3 \%$ and $24.7 \%$ for allergic rhinitis and nonallergic rhinitis, respectively. ${ }^{26)}$ According to these studies, LAR is a common disease that affects more than one fourth of adolescents and adults with nonallergic rhinitis.

Only a few studies on the prevalence of LAR in children have been conducted; thus, it is not well established compared to that in adults. The median prevalence of LAR in children previously diagnosed with nonallergic rhinitis was $44.4 \%$ (mean, $41.6 \%$; range, 3.7\%-66.6\%) according to available studies. ${ }^{25,27-32)}$

The clinical aspects of LAR are similar to those of allergic rhinitis; thus, significant conversions to LAR and systemic atopy were reported, while no evidence of LAR and the development of systemic atopy was observed in another study. ${ }^{33,34)}$ However, LAR seems to be related to future complications, which implies the possibility of LAR evolving into systemic allergic diseases. ${ }^{34,35)}$

\section{Idiopathic rhinitis}

Idiopathic rhinitis, previously known as vasomotor rhinitis, is also known as noninfectious nonallergic rhinitis. ${ }^{36}$ This phenotype has a multifactorial etiology that is triggered by cold air, particulate matter, and nonspecific chemicals. Links to irritant exposures including air pollution and secondary cigarette smoke were also reported in children. ${ }^{19,22,37)}$ Moreover, they induce a non-IgE-mediated inflammatory response and hyper-reactivity to mucosal components or neural innervations of the nose. ${ }^{36}$ )

Autonomic nervous system imbalance is a consistent finding in idiopathic rhinitis patients. Swelling of the nasal mucosa by cold stimulation results in this dysfunction versus vasoconstriction of the nasal mucosa in healthy controls. Dry cool air stimulation causes the largest reactions of the nasal mucosa in patients with idiopathic rhinitis versus allergic rhinitis patients and normal controls. ${ }^{38)}$ Autonomic nervous system dysfunction was significant in patients with idiopathic rhinitis versus controls. ${ }^{39)}$ Meanwhile, an ultrastructural study showed similarities between allergic rhinitis and idiopathic rhinitis. In idiopathic rhinitis patients, evidence of eosinophilic nitric oxide involvement or a better response to capsaicin treatment was not seen, suggesting underlying peptide-neurogenic inflammation. ${ }^{40)}$

Idiopathic rhinitis is a diagnosis of exclusion whose mechanism is not fully understood. Since it is diagnosed in a significant portion of rhinitis patients, revealing its etiology will enable better treatment options. ${ }^{41)}$

\section{Nonallergic rhinitis with eosinophilia syndrome}

NARES (also called eosinophilic nonallergic rhinitis) is defined as chronic rhinitis with nasal eosinophil infiltration but no IgE sensitization. ${ }^{36}$ Although there are different criteria for the diag. nosis of NARES, the distribution of $>20 \%$ nasal eosinophils is mandatory. ${ }^{42,43)}$ Originally described in the 1980s, NARES is estimated to affect 13\%-33\% of adult patients with nonallergic rhinitis. ${ }^{42,44)}$

Pediatric data on prevalence of NARES are scarce. Rupp and Friedman et al. ${ }^{45)}$ recorded 12 children with perennial rhinitis and nasal eosinophilia. Crobach et al. ${ }^{46)}$ assessed rhinitis patients aged 12 years or older by nasal smear and showed that 38 of the 363 subjects (10.5\%) had nasal eosinophilia ( $\geq 10 \%)$. Subsequently, they estimated the prevalence of NARES as being approximately $2 \%$. Thus, NARES in children seems to be rare, even more so in early childhood. ${ }^{46)}$

\section{Hormonal rhinitis}

Hormonal rhinitis related to hormonal changes accompanying pregnancy, menstruation, hypothyroidism, and acromegaly is rare in children. ${ }^{47)}$ Hormones induce vascular engorgement in the nose and cause rhinitis symptoms. Placenta growth hormones, in particular, are involved in nasal symptoms. ${ }^{48)}$ Estrogen is widely acknowledged to cause nasal congestion and engorgement. ${ }^{4-50)}$ Progesterone stimulation also reportedly causes nasal congestion, but this remains controversial. ${ }^{51)}$ However, earlier studies have suggested that changes in sex hormones that occur during the menstrual cycle affect the nasal mucosa, eventually causing nasal symptoms. ${ }^{52)}$ In contrary, testosterone inhibits eosinophil adhesion to mucosal endothelial cells, thereby leading to decreased eosinophilic activity and viability. ${ }^{47)}$

\section{Gustatory rhinitis}

Gustatory rhinitis is associated with the ingestion of hot or spicy foods. Excessive rhinorrhea occurs during food ingestion and begins within a few minutes after eating spicy food. Materials in spices such as capsaicin (8-methyl-n-vanillyl-6-nomamide) stimulate afferent sensory nerves in the oral and oropharyngeal mucosa, thereby triggering gustatory rhinitis. Its diagnosis relies on nasal symptoms reproduced while eating the causative food, 
and it is treated prophylactically with topical atropine. ${ }^{53-55)}$

Although observed in all age groups, gustatory rhinitis has a peak prevalence at 20-60 years. ${ }^{54)}$ However, the prevalence of gustatory rhinitis in pediatric populations remains unknown since children rarely ingest or use the causative agents (i.e., foods, smoking, or perfumes) and provocation tests for definite diag. nosis are not performed as easily as in adults.

\section{Increase in rhinitis and possible links with pollution}

Ambient air pollutant levels are higher in many Asian countries than in developed Western countries. ${ }^{56}$ The current increase in allergic and nonallergic rhinitis in developing countries may be attributable to these changes accompanied by the modernization process. ${ }^{56}$ Attention has increased on airborne particular matters (PM) with diameters less than $10 \mu \mathrm{m}\left(\mathrm{PM}_{10}\right)$ and $2.5 \mu \mathrm{m}\left(\mathrm{PM}_{2.5}\right)$ because they are suspected to be related with human health such as increased risks for cardiovascular diseases, diabetes, and adverse birth outcomes. Studies have questioned these associations, however, risk assessments of the fine particles affecting rhinitis are scarce. While traffic-related air pollution (TRAP) has been widely acknowledged to increase the risk for rhinitis, studies on PM exhibited conflicting results. A cohort study of 2,598 children suggested that exposure to TRAP during preg. nancy and the first year of life was related with the prevalence of allergic rhinitis later in childhood. ${ }^{57)}$ According to a crosssectional study from France, increased intranasal eosinophil levels were observed in asthma patients exposed to fine particles such as $\mathrm{PM}_{2.5}$, but not in children without asthma. ${ }^{58)}$ Large-scale nationwide surveys from Taiwan suggested that fine PM and $\mathrm{O}_{3}$ were not significantly related with an increased prevalence of rhinitis, whereas strong associations were observed between TRAP such as nitrogen oxides, carbon monoxide, and ozone. ${ }^{59,60)}$ Another study conducted in Taiwan concluded that children exposed to significantly higher levels of $\mathrm{SO}_{2}$ had a significantly higher incidence of allergic rhinitis at 12 years postexposure. ${ }^{61)}$

In a Chinese study that investigated 3,358 preschool children, gestational and early life exposure to $\mathrm{NO}_{2}$ was significantly associated with increased risks of rhinitis, whereas no significant association was found with exposure to $\mathrm{SO}_{2}$ and $\mathrm{PM}_{10} .^{62)} \mathrm{Like}$ wise, no causal link between $\mathrm{PM}_{10}$ levels and allergic rhinitis was revealed by a Korean study using geographic information systembased spatial modeling. ${ }^{63)}$ Meanwhile, possible relationships between the occurrence of rhinitis and high pollutant levels were implied in a prior study, which found that high pollutant levels were likely to lead to allergic rhinitis within the following week. ${ }^{64)}$ A large-scale study of approximately 70,000 United States children suggested that children living in areas with exposure to higher levels of $\mathrm{O}_{3}$ and $\mathrm{PM}_{2.5}$ were at higher risk of developing allergic rhinitis than children with lower exposure. ${ }^{65)}$ In a study that combined daily visits of allergic rhinitis patients consulting general practitioners and daily concentration of air pollutants, higher concentrations of $\mathrm{PM}_{10}$ and other air pollutants were associated with an increased likelihood of hospital visits. $\left.{ }^{6}{ }^{6}\right)$ Korean studies yielded similar results. One study including 5,443 children reported that living near a main road was associated with an increased prevalence of rhinitis, findings that were supported by another large-scale study of nearly 3,000 children. $67,68)$

Meanwhile, negative results have also been reported. A Canadian study of an elderly population suggests that air pollution exerts only minor effects on the exacerbation of rhinitis. ${ }^{69)}$ Health effects to allergic and nonallergic rhinitis caused by air pollution have become a sensitive topic in Asia, including South Korea and adjacent countries that have experienced rapid urbanization over the past few decades since ambient pollutant concentrations are higher than in other Western countries. Air pollutants represented by TRAP and fine PM exert a decisive effect on rhinitis throughout life, even during pregnancy. Investigations regarding relationships between pollutants and rhinitis are being reported constantly; however, the diagnosis of rhinitis in prior studies mainly relied on questionnaires, and rhinitis phenotypes were easily overlooked. ${ }^{70)}$ Therefore, the majority of studies were unable to reveal the diverse effects of air pollutants to allergic and nonallergic rhinitis. Additionally, metabolic activation, oxidative stress, mutagenicity/genotoxicity, and inflammation/immunity disorder caused by air pollutants have great potential to cause unfavorable effects in the respiratory system, but little is known about the relationship between these respiratory morbidities and rhinitis. ${ }^{71)}$ Few studies have focused on the influence of air pollution; most studies concentrated on its effects on the lower respiratory tract rather than the upper respiratory system. Further realistic investigations may be beneficial to increase our understanding of the relationship between rhinitis and air pollution.

\section{Diagnosis of nonallergic rhinitis}

Clinicians should consider that children with chronic rhinitis who are nonatopic may have nonallergic rhinitis. ${ }^{7)}$ To differentiate among the subtypes of nonallergic rhinitis, nasal provocation with allergen, microbiologic and cytologic evaluation, and IgE measurements of the nasal cavity are available in the clinical setting. ${ }^{7)}$ Previous studies have suggested that NPT is a feasible and safe tool with high diagnostic value in children with rhinitis; in this regard, LAR in children has been diagnosed using this method. ${ }^{25,30,72)}$ Recent studies have standardized and validated NPT in children. ${ }^{73,74)}$ Furthermore, NPT using Dermatophagoides pteronyssinus extract may be used to diagnose LAR. ${ }^{75)}$ Nasal hyper-reactivity to nonspecific triggers is a typical sign in idiopathic rhinitis, but is not routinely utilized in clinical practice for children. ${ }^{7,76)}$ 


\section{Treatment of nonallergic rhinitis}

Management of nonallergic rhinitis is essential due to its persistent and usually lifelong course. However, the treatment strategy of nonallergic rhinitis remains imprecise since its pathogenesis is poorly understood. ${ }^{6,76)}$

\section{Conventional treatment strategies with remedy used in allergic rhinitis}

In LAR and nonallergic rhinitis, the combination of intranasal antihistamine and intranasal corticosteroid is the most effective treatment. Symptoms of drug-induced rhinitis caused by autonomous system abnormality induced by nonsteroidal antiinflammatory drugs may be relieved by the administration of ipratropium bromide or capsaicin. ${ }^{6}$ )

In a clinical trial of 59 adults with rhinitis, intranasal corticosteroids effectively treated both allergic and nonallergic rhinitis. ${ }^{77}$ Another clinical trial of children aged 12 years and older reported that intranasal corticosteroid was more effective in nonallergic rhinitis patients than in the control group regardless of eosinophilia. ${ }^{78)}$ Intranasal corticosteroids were reportedly effective in rhinitis patients with nasal eosinophilia. ${ }^{79)}$ NARES is also known to respond relatively well to intranasal corticosteroids. 36,44) However, other studies yielded different results regarding the effects of intranasal corticosteroid on nonallergic rhinitis. The application of intranasal corticosteroids in adolescents and adults with nonallergic rhinitis for longer than 8 weeks did not relieve rhinitis symptoms. ${ }^{80)}$ Intranasal corticosteroids as a treatment option for nonallergic rhinitis subtypes with overlapping pathophysiology of allergic rhinitis may be alluded to by these clinical trials.

\section{Combination of intranasal corticosteroid and azelastin}

A combination nasal spray of azelastin hydrochloride and fluticasone propionate (MP29-02; Dymista, Meda Pharmaceuticals, Somerset, NJ, USA) was recently confirmed as an effective and safe medication regimen. ${ }^{81,82)}$ Azelastin desensitizes transient receptor potential (TRP) channels, while fluticasone propionate inhibits degranulation of mast cells. ${ }^{83)}$ TRP channels are distributed broadly throughout the nasal mucosa and known to be involved in the response to multiple stimuli including temperature and osmolality changes. Furthermore, TRP channel dysfunction in respiratory disease leads to alterations in vascular permeability, inflammation, mucus secretion, and mucociliary clearance. Recently, therapeutic agents that modulate specific TRP channel function have been introduced in various respiratory diseases, while the transient receptor potential vanilloid 1 (TRPV1) channel is reportedly upregulated in idiopathic rhinitis. ${ }^{84)}$ The combination spray MP29-02, which reduces nasal hyper-reactivity, is widely acknowledged to be effective in allergic rhinitis patients. ${ }^{83,85)}$ In children, a 3-month maintenance duration of MP-AzeFlu exerted a more immediate response than fluticasone propionate alone. ${ }^{86)}$ Complete response, defined as a $100 \%$ reduction in evening reflective Total Nasal Symptom Score, was observed 9 days earlier during the first 28-day treatment period in 7 of 10 patients on the combination therapy. A previous study concluded that the long-term use of MP29-02 was superior to monotherapy with intranasal corticosteroid in patients with chronic rhinitis and that those with significant components of nonallergic rhinitis might benefit from this combination therapy considering the overlapping mechanisms. ${ }^{87,88)}$

Capsaicin TRPV1 agonist has also been tested for the treatment of nonallergic rhinitis. ${ }^{89)}$ The first controlled trial demonstrated that a 2-week regimen of intranasal capsaicin, a TRPV1 agonist, rapidly and safely improved symptoms in rhinitis subjects with significant nonallergic rhinitis components. ${ }^{90)}$

\section{Combination of intranasal corticosteroid and decongestant}

An alpha-adrenoceptor with a rapid onset and long duration of action is effective for nasal congestion. ${ }^{91)}$ However, rhinitis medicamentosa, tachyphylaxis, and rebound congestion are obstacles related to its long-term administration. ${ }^{92)}$ An animal study of combination xylometazoline and intranasal corticosteroid showed the benefit of minimizing long-term usage due to associated congestion, edema, inflammatory cell infiltration, epithelial degeneration, and nasociliary loss in the nasal mucosa of rabbits. ${ }^{93)}$ The 14-day administration of intranasal corticosteroid to patients with rhinitis medicamentosa resulted in significant symptom improvement. ${ }^{94)}$ Intranasal corticosteroid treatment in allergic rhinitis patients after a 3-week maintenance regimen with oxymetazoline eliminated rebound congestion within 48 hours versus 1 week in the placebo group. ${ }^{95)}$ In healthy adults, intranasal corticosteroid improved tachyphylaxis and congestion after oxymetazoline treatment. ${ }^{96}$ ) The combination treatment regimen of intranasal corticosteroid and oxymetazoline also improved nasal obstruction, hyposmia, peak flow, total polyps score, and nasal mucociliary clearance time in adults with nasal polyps. ${ }^{97)}$ A recent study of intranasal corticosteroid nonrespondent children with adenoid hypertrophy and allergic rhinitis showed that the combination of intranasal corticosteroid and oxymetazoline significantly increased nasal volume. ${ }^{91)}$ Several recent studies proved that the concomitant use of intranasal decongestant with intranasal corticosteroid might prevent rhinitis medicamentosa while improving nasal congestion versus monotherapy in patients with nonallergic rhinitis. ${ }^{88)}$

Given the results of the studies mentioned above, the combined use of nasal steroids and decongestants might be more effective than nasal steroids alone.

\section{Other treatments}

The use of radiofrequency ablation for the treatment of inferior turbinate hypertrophy was studied in patients with allergic versus nonallergic rhinitis. Low-frequency kinetic oscillation stimulation of the nasal mucosa may be an effective short-term treatment for nonallergic rhinitis patients with nasal congestion. ${ }^{88)}$

The presence of inflammation in the pathogenesis of rhinitis is an important guide in the creation of treatment strategies. Various mediators including histamine, TAME esterase, kinins, pro- 
staglandins, and leukotrienes released in cold stimulation may be considered in nonallergic rhinitis patients responding less to antihistamine or intranasal corticosteroid. ${ }^{36}$ The administration of intranasal corticosteroid or antihistamine may have no effect if the main mechanism of rhinitis is not an inflammatory response.

\section{Conclusion}

Here, we reviewed the published literature regarding the prevalence, phenotypes, comorbidities, and treatment of nonallergic rhinitis in children. The prevalence and etiology of some phenotypes of nonallergic rhinitis in children are well defined, but information about other rhinitis phenotypes remains uncertain. Moreover, data of nonallergic rhinitis in early children are scarce. Prospective randomized double-blind placebo-controlled crossover studies are warranted to ensure our comprehensive understanding and enable clinicians and scientists to provide accurate diagnostic and therapeutic approaches to childhood nonallergic rhinitis.

\section{Footnotes}

Conflicts of interest: No potential conflict of interest relevant to this article was reported.

\section{References}

1. Magnusson J, Kull I, Westman M, Hakansson N, Wolk A, Melen E, et al. Fish and polyunsaturated fat intake and development of allergic and nonallergic rhinitis. J Allergy Clin Immunol 2015;136:1247-53.e1-2.

2. Roberts G, Xatzipsalti M, Borrego LM, Custovic A, Halken S, Hellings PW, et al. Paediatric rhinitis: position paper of the European Academy of Allergy and Clinical Immunology. Allergy 2013;68:1102-16.

3. Bachert C, van Cauwenberge P, Olbrecht J, van Schoor J. Prevalence, classification and perception of allergic and nonallergic rhinitis in Belgium. Allergy 2006;61:693-8.

4. Bousquet J, Fokkens W, Burney P, Durham SR, Bachert C, Akdis CA, et al. Important research questions in allergy and related diseases: nonallergic rhinitis: a GA2LEN paper. Allergy 2008;63:842-53.

5. Poddighe D, Gelardi M, Licari A, Del Giudice MM, Marseglia GL. Nonallergic rhinitis in children: Epidemiological aspects, pathological features, diagnostic methodology and clinical management. World J Methodol 2016;6:200-13.

6. Lieberman PL, Smith P. Nonallergic rhinitis: treatment. Immunol Allergy Clin North Am 2016;36:305-19.

7. Hellings PW, Klimek L, Cingi C, Agache I, Akdis C, Bachert C, et al. Nonallergic rhinitis: position paper of the European Academy of Allergy and Clinical Immunology. Allergy 2017;72:1657-65.

8. Ha EK, Park JH, Lee SJ, Yon DK, Kim JH, Jee HM, et al. Shared and unique individual risk factors and clinical biomarkers in children with allergic rhinitis and obstructive sleep apnea syndrome. Clin Respir J 2020; 14:250-9.

9. Chiang WC, Chen YM, Tan HK, Balakrishnan A, Liew WK, Lim HH, et al. Allergic rhinitis and non-allergic rhinitis in children in the tropics: prevalence and risk associations. Pediatr Pulmonol 2012;47:1026-33.

10. Arshad SH, Holloway JW, Karmaus W, Zhang H, Ewart S, Mansfield L, et al. Cohort profile: the Isle Of Wight Whole Population Birth Cohort
(IOWBC). Int J Epidemiol 2018;47:1043-4i.

11. Arshad SH, Tariq SM, Matthews S, Hakim E. Sensitization to common allergens and its association with allergic disorders at age 4 years: a whole population birth cohort study. Pediatrics 2001;108:E33.

12. Arshad SH, Kurukulaaratchy RJ, Fenn M, Waterhouse L, Matthews S. Rhinitis in 10-year-old children and early life risk factors for its development. Acta Paediatr 2002;91:1334-8.

13. Arshad SH, Stevens M, Hide DW. The effect of genetic and environmental factors on the prevalence of allergic disorders at the age of two years. Clin Exp Allergy 1993;23:504-11.

14. Kulig M, Klettke U, Wahn V, Forster J, Bauer CP, Wahn U. Development of seasonal allergic rhinitis during the first 7 years of life. J Allergy Clin Immunol 2000;106:832-9.

15. Westman M, Stjarne P, Asarnoj A, Kull I, van Hage M, Wickman M, et al. Natural course and comorbidities of allergic and nonallergic rhinitis in children. J Allergy Clin Immunol 2012;129:403-8.

16. Marinho S, Simpson A, Lowe L, Kissen P, Murray C, Custovic A. Rhinoconjunctivitis in 5-year-old children: a population-based birth cohort study. Allergy 2007;62:385-93.

17. Chawes BL, Bonnelykke K, Kreiner-Moller E, Bisgaard H. Children with allergic and nonallergic rhinitis have a similar risk of asthma. J Allergy Clin Immunol 2010;126:567-73.e1-8.

18. Ha EK, Baek JH, Lee SY, Park YM, Kim WK, Sheen YH, et al. Association of polysensitization, allergic multimorbidity, and allergy severity: a crosssectional study of school children. Int Arch Allergy Immunol 2016;171: 251-60.

19. Baek JH, Cho E, Kim MA, Lee SW, Kang YS, Sheen YH, et al. Response to nonallergenic irritants in children with allergic and nonallergic rhinitis. Allergy Asthma Immunol Res 2016;8:346-52.

20. Topal E, Bakirtas A, Yilmaz O, Karagol IH, Arslan U, Arga M, et al. Predictive factors to differentiate between allergic and nonallergic rhinitis in children. Int Forum Allergy Rhinol 2014;4:447-52.

21. Song JY, Ha EK, Sheen YH, Kim MA, Lee SW, Yoon JW, et al. The association of nasal patency with small airway resistance in children with allergic and nonallergic rhinitis. Clin Respir J 2018;12:2264-70.

22. Pinart M, Benet M, Annesi-Maesano I, von Berg A, Berdel D, Carlsen KC, et al. Comorbidity of eczema, rhinitis, and asthma in IgE-sensitised and non-IgE-sensitised children in MeDALL: a population-based cohort study. Lancet Respir Med 2014;2:131-40.

23. Herr M, Clarisse B, Nikasinovic L, Foucault C, Le Marec AM, Giordanella JP, et al. Does allergic rhinitis exist in infancy? Findings from the PARIS birth cohort. Allergy 2011;66:214-21.

24. Hardjojo A, Goh A, Shek LP, Van Bever HP, Teoh OH, Soh JY, et al. Rhinitis in the first 18 months of life: exploring the role of respiratory viruses. Pediatr Allergy Immunol 2015;26:25-33.

25. Ha EK, Na MS, Lee S, Baek H, Lee SJ, Sheen YH, et al. Prevalence and clinical characteristics of local allergic rhinitis in children sensitized to house dust mites. Int Arch Allergy Immunol 2017;174:183-9.

26. Hamizan AW, Rimmer J, Alvarado R, Sewell WA, Kalish L, Sacks R, et al. Positive allergen reaction in allergic and nonallergic rhinitis: a systematic review. Int Forum Allergy Rhinol 2017;7:868-77.

27. Fuiano N, Fusilli S, Incorvaia C. A role for measurement of nasal IgE antibodies in diagnosis of Alternaria-induced rhinitis in children. Allergol Immunopathol (Madr) 2012;40:71-4.

28. Krajewska-Wojtys A, Jarzab J, Gawlik R, Bozek A. Local allergic rhinitis to pollens is underdiagnosed in young patients. Am J Rhinol Allergy 2016; 30:198-201.

29. Zicari AM, Occasi F, Di Fraia M, Mainiero F, Porzia A, Galandrini R, et al. Local allergic rhinitis in children: novel diagnostic features and potential biomarkers. Am J Rhinol Allergy 2016;30:329-34.

30. Duman H, Bostanci I, Ozmen S, Dogru M. The relevance of nasal provocation testing in children with nonallergic rhinitis. Int Arch Allergy Immunol 2016;170:115-21.

31. Blanca-Lopez N, Campo P, Salas M, Garcia Rodriguez C, Palomares F, Blanca $\mathrm{M}$, et al. Seasonal local allergic rhinitis in areas with high concentrations of grass pollen. J Investig Allergol Clin Immunol 2016;26:83-91.

32. Buntarickpornpan P, Veskitkul J, Pacharn P, Visitsunthorn N, Vichyanond 
P, Tantilipikorn P, et al. The proportion of local allergic rhinitis to Dermatophagoides pteronyssinus in children. Pediatr Allergy Immunol 2016;27: 574-9.

33. Sennekamp J, Joest I, Filipiak-Pittroff B, von Berg A, Berdel D. Local allergic nasal reactions convert to classic systemic allergic reactions: a longterm follow-up. Int Arch Allergy Immunol 2015;166:154-60.

34. Rondon C, Campo P, Eguiluz-Gracia I, Plaza C, Bogas G, Galindo P, et al. Local allergic rhinitis is an independent rhinitis phenotype: the results of a 10-year follow-up study. Allergy 2018;73:470-8.

35. Rondon C, Campo P, Zambonino MA, Blanca-Lopez N, Torres MJ, Melendez L, et al. Follow-up study in local allergic rhinitis shows a consistent entity not evolving to systemic allergic rhinitis. J Allergy Clin Immunol 2014;133:1026-31.

36. Fokkens WJ. Thoughts on the pathophysiology of nonallergic rhinitis. Curr Allergy Asthma Rep 2002;2:203-9.

37. Yon DK, Hwang S, Lee SW, Jee HM, Sheen YH, Kim JH, et al. Indoor exposure and sensitization to formaldehyde among inner-city children with increased risk for asthma and rhinitis. Am J Respir Crit Care Med 2019;200:388-93.

38. Numata T, Konno A, Hasegawa S, Hanazawa T, Nagata H, Motosugi $\mathrm{H}$, et al. Pathophysiological features of the nasal mucosa in patients with idiopathic rhinitis compared to allergic rhinitis. Int Arch Allergy Immunol 1999;119:304-13.

39. Jaradeh SS, Smith TL, Torrico L, Prieto TE, Loehrl TA, Darling RJ, et al. Autonomic nervous system evaluation of patients with vasomotor rhinitis. Laryngoscope 2000;110:1828-31.

40. Knipping S, Holzhausen HJ, Riederer A, Schrom T. Allergic and idiopathic rhinitis: an ultrastructural study. Eur Arch Otorhinolaryngol 2009;266: 1249-56.

41. van Rijswijk JB, Blom HM, Fokkens WJ. Idiopathic rhinitis, the ongoing quest. Allergy 2005;60:1471-81.

42. Ellis AK, Keith PK. Nonallergic rhinitis with eosinophilia syndrome. Curr Allergy Asthma Rep 2006;6:215-20.

43. Schiavino D, Nucera E, Milani A, Della Corte AM, D'Ambrosio C, Pag. liari $G$, et al. Nasal lavage cytometry in the diagnosis of nonallergic rhinitis with eosinophilia syndrome (NARES). Allergy Asthma Proc 1997;18: 363-6.

44. Mullarkey MF, Hill JS, Webb DR. Allergic and nonallergic rhinitis: their characterization with attention to the meaning of nasal eosinophilia. J Allergy Clin Immunol 1980;65:122-6.

45. Rupp GH, Friedman RA. Eosinophilic nonallergic rhinitis in children. Pediatrics 1982;70:437-9.

46. Crobach M, Hermans J, Kaptein A, Ridderikhoff J, Mulder J. Nasal smear eosinophilia for the diagnosis of allergic rhinitis and eosinophilic nonallergic rhinitis. Scand J Prim Health Care 1996;14:116-21.

47. Bachert C. Persistent rhinitis - allergic or nonallergic? Allergy 2004;59 Suppl 76:11-5; discussion 5 .

48. Ellegard EK, Karlsson NG, Ellegard LH. Rhinitis in the menstrual cycle, pregnancy, and some endocrine disorders. Clin Allergy Immunol 2007;19:305-21.

49. Ellegard E, Karlsson G. Nasal congestion during the menstrual cycle. Clin Otolaryngol Allied Sci 1994;19:400-3.

50. Philpott CM, El-Alami M, Murty GE. The effect of the steroid sex hormones on the nasal airway during the normal menstrual cycle. Clin Otolaryngol Allied Sci 2004;29:138-42.

51. Kaliner MA. Classification of nonallergic rhinitis syndromes with a focus on vasomotor rhinitis, proposed to be known henceforth as nonallergic rhinopathy. World Allergy Organ J 2009;2:98-101.

52. Navarrete-Palacios E, Hudson R, Reyes-Guerrero G, Guevara-Guzman R. Correlation between cytological characteristics of the nasal epithelium and the menstrual cycle. Arch Otolaryngol Head Neck Surg 2003;129: 460-3.

53. Raphael G, Raphael MH, Kaliner M. Gustatory rhinitis: a syndrome of food-induced rhinorrhea. J Allergy Clin Immunol 1989;83:110-5.

54. Georgalas C, Jovancevic L. Gustatory rhinitis. Curr Opin Otolaryngol Head Neck Surg 2012;20:9-14.

55. Philip G, Baroody FM, Proud D, Naclerio RM, Togias AG. The human nasal response to capsaicin. J Allergy Clin Immunol 1994;94(6 Pt 1): 1035-45.

56. Leung TF, Ko FW, Wong GW. Roles of pollution in the prevalence and exacerbations of allergic diseases in Asia. J Allergy Clin Immunol 2012; 129:42-7.

57. Deng Q, Lu C, Yu Y, Li Y, Sundell J, Norback D. Early life exposure to traffic-related air pollution and allergic rhinitis in preschool children. Respir Med 2016;121:67-73.

58. Nikasinovic L, Just J, Sahraoui F, Seta N, Grimfeld A, Momas I. Nasal inflammation and personal exposure to fine particles PM2.5 in asthmatic children. J Allergy Clin Immunol 2006;117:1382-8.

59. Lee YL, Shaw CK, Su HJ, Lai JS, Ko YC, Huang SL, et al. Climate, trafficrelated air pollutants and allergic rhinitis prevalence in middle-school children in Taiwan. Eur Respir J 2003;21:964-70.

60. Hwang BF, Jaakkola JJ, Lee YL, Lin YC, Guo YL. Relation between air pollution and allergic rhinitis in Taiwanese schoolchildren. Respir Res 2006;7:23.

61. Chiang TY, Yuan TH, Shie RH, Chen CF, Chan CC. Increased incidence of allergic rhinitis, bronchitis and asthma, in children living near a petrochemical complex with SO2 pollution. Environ Int 2016;96:1-7.

62. Liu W, Huang C, Hu Y, Fu Q, Zou Z, Sun C, et al. Associations of gestational and early life exposures to ambient air pollution with childhood respiratory diseases in Shanghai, China: A retrospective cohort study. Environ Int 2016;92-93:284-93.

63. Seo S, Kim D, Min S, Paul C, Yoo Y, Choung JT. GIS-based association between PM10 and allergic diseases in Seoul: implications for health and environmental policy. Allergy Asthma Immunol Res 2016;8:32-40.

64. Chung HY, Hsieh CJ, Tseng CC, Yiin LM. Association between the first occurrence of allergic rhinitis in preschool children and air pollution in Taiwan. Int J Environ Res Public Health 2016;13:268.

65. Parker JD, Akinbami LJ, Woodruff TJ. Air pollution and childhood respiratory allergies in the United States. Environ Health Perspect 2009;117: 140-7.

66. Zhang F, Wang W, Lv J, Krafft T, Xu J. Time-series studies on air pollution and daily outpatient visits for allergic rhinitis in Beijing, China. Sci Total Environ 2011;409:2486-92.

67. Jung DY, Leem JH, Kim HC, Kim JH, Hwang SS, Lee JY, et al. Effect of traffic-related air pollution on allergic disease: results of the children's health and environmental research. Allergy Asthma Immunol Res 2015; 7:359-66.

68. Zuraimi MS, Tham KW, Chew FT, Ooi PL, Koh D. Home air-conditioning, traffic exposure, and asthma and allergic symptoms among preschool children. Pediatr Allergy Immunol 2011;22(1 Pt 2):e112-8.

69. Villeneuve PJ, Doiron MS, Stieb D, Dales R, Burnett RT, Dugandzic R. Is outdoor air pollution associated with physician visits for allergic rhinitis among the elderly in Toronto, Canada? Allergy 2006;61:750-8.

70. Teng B,Zhang X, Yi C, Zhang Y, YeS, Wang Y, etal. The association between ambient air pollution and allergic rhinitis: further epidemiological evidence from Changchun, Northeastern China. Int J Environ Res Public Health 2017; 14:226

71. Feng S, Gao D, Liao F, Zhou F, Wang X. The health effects of ambient PM2.5 and potential mechanisms. Ecotoxicol Environ Saf 2016;128:6774.

72. Jean R, Rufin P, Pfister A, Landais P, Waernessyckle S, de Blic J, et al. Diagnostic value of nasal provocation challenge with allergens in children. Allergy 1998;53:990-4.

73. Auge J, Vent J, Agache I, Airaksinen L, Campo Mozo P, Chaker A, et al. EAACI Position paper on the standardization of nasal allergen challenges. Allergy 2018;73:1597-608.

74. Jang TY, Kim YH. Nasal provocation test is useful for discriminating allergic, nonallergic, and local allergic rhinitis. Am J Rhinol Allergy 2015; 29:e100-4.

75. de Blay F, Doyen V, Lutz C, Godet J, Barnig C, Qi S, et al. A new, faster, and safe nasal provocation test method for diagnosing mite allergic rhinitis. Ann Allergy Asthma Immunol 2015;115:385-90.e1.

76. Baraniuk JN, Kim D. Nasonasal reflexes, the nasal cycle, and sneeze. Curr Allergy Asthma Rep 2007;7:105-11. 
77. Wight RG, Jones AS, Beckingham E, Andersson B, Ek L. A double blind comparison of intranasal budesonide 400 micrograms and 800 micrograms in perennial rhinitis. Clin Otolaryngol Allied Sci 1992;17:354-8.

78. Webb DR, Meltzer EO, Finn AF Jr, Rickard KA, Pepsin PJ, Westlund R, et al. Intranasal fluticasone propionate is effective for perennial nonallergic rhinitis with or without eosinophilia. Ann Allergy Asthma Immunol 2002; 88:385-90.

79. Small P, Black M, Frenkiel S. Effects of treatment with beclomethasone dipropionate in subpopulations of perennial rhinitis patients. J Allergy Clin Immunol 1982;70:178-82.

80. Blom HM, Godthelp T, Fokkens WJ, KleinJan A, Mulder PG, Rijntjes E. The effect of nasal steroid aqueous spray on nasal complaint scores and cellular infiltrates in the nasal mucosa of patients with nonallergic, noninfectious perennial rhinitis. J Allergy Clin Immunol 1997;100(6 Pt 1):73947.

81. Derendorf H, Munzel U, Petzold U, Maus J, Mascher H, Hermann R, et al. Bioavailability and disposition of azelastine and fluticasone propionate when delivered by MP29-02, a novel aqueous nasal spray. Br J Clin Pharmacol 2012;74:125-33.

82. Berger WE, Shah S, Lieberman P, Hadley J, Price D, Munzel U, et al. Longterm, randomized safety study of MP29-02 (a novel intranasal formulation of azelastine hydrochloride and fluticasone propionate in an advanced delivery system) in subjects with chronic rhinitis. J Allergy Clin Immunol Pract 2014;2:179-85.

83. Kortekaas Krohn I, Callebaut I, Alpizar YA, Steelant B, Van Gerven L, Skov PS, et al. MP29-02 reduces nasal hyperreactivity and nasal mediators in patients with house dust mite-allergic rhinitis. Allergy 2018;73:1084-93.

84. Fokkens W, Hellings P, Segboer C. Capsaicin for Rhinitis. Curr Allergy Asthma Rep 2016;16:60.

85. Carr W, Bernstein J, Lieberman P, Meltzer E, Bachert C, Price D, et al. A novel intranasal therapy of azelastine with fluticasone for the treatment of allergic rhinitis. J Allergy Clin Immunol 2012;129:1282-9.e10.

86. Berger W, Bousquet J, Fox AT, Just J, Muraro A, Nieto A, et al. MP-AzeFlu is more effective than fluticasone propionate for the treatment of allergic rhinitis in children. Allergy 2016;71:1219-22.

87. Price D, Shah S, Bhatia S, Bachert C, Berger W, Bousquet J, et al. A new therapy (MP29-02) is effective for the long-term treatment of chronic rhinitis. J Investig Allergol Clin Immunol 2013;23:495-503.

88. Brown KR, Bernstein JA. Clinically relevant outcome measures of novel pharmacotherapy for nonallergic rhinitis. Curr Opin Allergy Clin Im. munol 2015; 15:204-12.

89. Van Gerven L, Alpizar YA, Steelant B, Callebaut I, Kortekaas Krohn I, Wouters $\mathrm{M}$, et al. Enhanced chemosensory sensitivity in patients with idiopathic rhinitis and its reversal by nasal capsaicin treatment. J Allergy Clin Immunol 2017; 140:437-46.e2.

90. Bernstein JA, Davis BP, Picard JK, Cooper JP, Zheng S, Levin LS. A randomized, double-blind, parallel trial comparing capsaicin nasal spray with placebo in subjects with a significant component of nonallergic rhinitis. Ann Allergy Asthma Immunol 2011;107:171-8.

91. Liu W, Zhou L, Zeng Q, Luo R. Combination of mometasone furoate and oxymetazoline for the treatment of adenoid hypertrophy concomitant with allergic rhinitis: a randomized controlled trial. Sci Rep 2017;7:40425.

92. Lockey RF. Rhinitis medicamentosa and the stuffy nose. J Allergy Clin Immunol 2006;118:1017-8.

93. Akpinar ME, Yigit O, Akakin D, Sarioz O, Ozkan N, Yildiz SD, et al. Topical glucocorticoid reduces the topical decongestant-induced histologic changes in an animal model nasal mucosa. Laryngoscope 2012;122:741-6.

94. Hallen H, Enerdal J, Graf P. Fluticasone propionate nasal spray is more effective and has a faster onset of action than placebo in treatment of rhinitis medicamentosa. Clin Exp Allergy 1997;27:552-8.

95. Ferguson BJ, Paramaesvaran S, Rubinstein E. A study of the effect of nasal steroid sprays in perennial allergic rhinitis patients with rhinitis medicamentosa. Otolaryngol Head Neck Surg 2001;125:253-60.

96. Vaidyanathan S, Williamson P, Clearie K, Khan F, Lipworth B. Fluticasone reverses oxymetazoline-induced tachyphylaxis of response and rebound congestion. Am J Respir Crit Care Med 2010;182:19-24.

97. Kirtsreesakul V, Khanuengkitkong T, Ruttanaphol S. Does oxymetazoline increase the efficacy of nasal steroids in treating nasal polyposis? Am J Rhinol Allergy 2016;30:195-200.

98. Sears MR, Burrows B, Flannery EM, Herbison GP, Holdaway MD. Atopy in childhood. I. Gender and allergen related risks for development of hay fever and asthma. Clin Exp Allergy 1993;23:941-8.

99. Porro E, Calamita P, Rana I, Montini L, Criscione S. Atopy and environmental factors in upper respiratory infections: an epidemiological survey on 2304 school children. Int J Pediatr Otorhinolaryngol 1992;24:11120.

100. Braun-Fahrlander C, Wuthrich B, Gassner M, Grize L, Sennhauser $\mathrm{FH}$, Varonier HS, et al. Validation of a rhinitis symptom questionnaire (ISAAC core questions) in a population of Swiss school children visiting the school health services. SCARPOL-team. Swiss Study on Childhood Allergy and Respiratory Symptom with respect to Air Pollution and Climate. International Study of Asthma and Allergies in Childhood. Pediatr Allergy Immunol 1997;8:75-82.

101. Wright AL, Holberg CJ, Martinez FD, Halonen M, Morgan W, Taussig LM. Epidemiology of physician-diagnosed allergic rhinitis in childhood. Pediatrics 1994;94(6 Pt 1):895-901.

102. Keles N, Ilicali C, Deger K. The effects of different levels of air pollution on atopy and symptoms of allergic rhinitis. Am J Rhinol 1999;13:18590.

103. Soto-Quiros ME, Silverman EK, Hanson LA, Weiss ST, Celedon JC. Maternal history, sensitization to allergens, and current wheezing, rhinitis, and eczema among children in Costa Rica. Pediatr Pulmonol 2002;33:237-43.

104. Kurukulaaratchy RJ, Karmaus W, Raza A, Matthews S, Roberts G, Arshad $\mathrm{SH}$. The influence of gender and atopy on the natural history of rhinitis in the first 18 years of life. Clin Exp Allergy 2011;41:851-9.

105. Kuyucu S, Saraclar Y, Tuncer A, Geyik PO, Adalioglu G, Akpinarli A, et al. Epidemiologic characteristics of rhinitis in Turkish children: the International Study of Asthma and Allergies in Childhood (ISAAC) phase 2. Pediatr Allergy Immunol 2006;17:269-77.

106. Carr TF, Stern DA, Halonen M, Wright AL, Martinez FD. Non-atopic rhinitis at age 6 is associated with subsequent development of asthma. Clin Exp Allergy 2019;49:35-43.

107. Papadopoulou A, Hatziagorou E, Matziou VN, Grigoropoulou DD, Panagiotakos DB, Tsanakas JN, et al. Comparison in asthma and allergy prevalence in the two major cities in Greece: the ISAAC phase II survey. Allergol Immunopathol (Madr) 2011;39:347-55.

108. Ulrik CS, von Linstow ML, Backer V. Prevalence and predictors of rhinitis in Danish children and adolescents. Allergy 2000;55:1019-24.

109. Belgrave DC, Granell R, Simpson A, Guiver J, Bishop C, Buchan I, et al. Developmental profiles of eczema, wheeze, and rhinitis: two populationbased birth cohort studies. PLoS Med 2014;11:e1001748.

110. Bahceciler NN, Ozdemir C, Kucukosmanoglu E, Arikan C, Over U, Karavelioglu S, et al. Association between previous enterobiasis and current wheezing: evaluation of 1018 children. Allergy Asthma Proc 2007;28:174-82.

111. Kurukulaaratchy RJ, Matthews S, Arshad SH. Defining childhood atopic phenotypes to investigate the association of atopic sensitization with allergic disease. Allergy 2005;60:1280-6.

112. Kim SH, Kim YK, Lee MH, Hong SC, Bae JM, Min KU, et al. Relationship between sensitization to citrus red mite (Panonychus citri) and the prevalence of atopic diseases in adolescents living near citrus orchards. Clin Exp Allergy 2002;32:1054-8.

113. Bertelsen RJ, Carlsen KC, Carlsen KH. Rhinitis in children: co-morbidities and phenotypes. Pediatr Allergy Immunol 2010;21(4 Pt 1):61222.

114. Sobki SH, Zakzouk SM. Point prevalence of allergic rhinitis among Saudi children. Rhinology 2004;42:137-40.

115. Kong WJ, Chen JJ, Zheng ZY, Shi QM, Zhou Y. Prevalence of allergic rhinitis in 3-6-year-old children in Wuhan of China. Clin Exp Allergy 2009;39:869-74.

116. Han YY, Forno E, Gogna M, Celedon JC. Obesity and rhinitis in a nationwide study of children and adults in the United States. J Allergy Clin Immunol 2016;137:1460-5. 
117. Zhang YM, Zhang J, Liu SL, Zhang X, Yang SN, Gao J, et al. Prevalence and associated risk factors of allergic rhinitis in preschool children in Beijing. Laryngoscope 2013;123:28-35.

118. Lee SH, Choi JH, Suh JD, Chung S, Hong SC, Kim JK, et al. Natural Course of allergic and nonallergic rhinitis after 2 years in Korean children. Clin Exp Otorhinolaryngol 2016;9:233-7.

119. Lee KS, Yum HY, Sheen YH, Park YM, Lee YJ, Choi BS, et al. Comorbidities and phenotypes of rhinitis in Korean children and adolescents: a cross-sectional, multicenter study. Allergy Asthma Immunol Res 2017; 9:70-8.

120. Ahn JY, Kim JE, Choi BS. Symptomatic differences between allergic and nonallergic rhinitis in children. Allergy Asthma Respir Dis 2015;3:341-5.

121. Kim DK, Rhee CS, Han DH, Won TB, Kim DY, Kim JW. Treatment of allergic rhinitis is associated with improved attention performance in children: the Allergic Rhinitis Cohort Study for Kids (ARCO-Kids). PLoS One 2014;9:e109145.

122. Won NH, Park SH, Ahn SH, Kim CB, Kwon JH, Seo WH, et al. Clinical characteristics of allergic rhinitis and nonallergic rhinitis in Korean children. Allergy Asthma Respir Dis 2020;8:20-9.

123. Molgaard E, Thomsen SF, Lund T, Pedersen L, Nolte H, Backer V. Differences between allergic and nonallergic rhinitis in a large sample of adolescents and adults. Allergy 2007;62:1033-7.

124. Kim SW, Han DH, Lee SJ, Lee CH, Rhee CS. Bronchial hyperresponsiveness in pediatric rhinitis patients: the difference between allergic and nonallergic rhinitis. Am J Rhinol Allergy 2013;27:e63-8.

125. Gelardi M, Iannuzzi L, Tafuri S, Passalacqua G, Quaranta N. Allergic and non-allergic rhinitis: relationship with nasal polyposis, asthma and family history. Acta Otorhinolaryngol Ital 2014;34:36-41.

How to cite this article: Yum HY, Ha EK, Shin YH, Han MY. Nonallergic rhinitis in children. Clin Exp Pediatr 2021;64:37383. https://doi.org/10.3345/cep.2020.00822 